\title{
MEMORY WORK
}

\author{
Delia D. Aguilar \\ deliaaguilar@yahoo.com
}

\begin{abstract}
In this piece of memory work, Delia Aguilar reflects on the meaning of coming home from exile. Aguilar opens with a story of a trip where the author and E. San Juan, Jr. regarded the ruins of Escolta, Manila's former fashionable district. Using this story, Aguilar meditates on the ethics of memory and the politics of witnessing history. This is the history of her partnership with San Juan in which their embrace of radical politics has become their way of coming alive to a world marked by "the banality and dreariness of the quotidian." For Aguilar, to speak about this history is not only to witness, but also to come home.
\end{abstract}

\section{Keywords}

E. San Juan, Jr., homecoming, memory work, witnessing

\section{About the Author}

Delia D. Aguilar has a long history of engagement with the women's movements in the Philippines and the United States. Her first three books, published in the Philippines, were a result of that engagement. A fourth, an anthology titled Women and Globalization, emphasizes the central role of women's labor in globalized production. Aguilar's most recent teaching has been in women's studies at the University of Connecticut, before which she held tenured appointments in women's studies and ethnic studies at Washington State University and Bowling Green State University. She was Irwin Chair in women's studies at Hamilton College in 20082009 and a fellow at the Bunting Institute in 1992. She has also taught at the University of the Philippines. 
When Charlie invited me to take part in this symposium, my immediate response was to decline. I do not believe that being Sonny's life-long partner necessarily equips me to write about his work and so I really had no idea what I could possibly contribute. But Charlie pressed, and I finally accepted with the caveat that I be put last and given the option to back out at the last minute. Memory work, I thought, was a broad enough title to afford me room for maneuver, but even so I did not know what memories to share.

Without being aware of it then, my travail de memoire inadvertently began late January when Charlie took Sonny and me on a Chinatown tour that included a walk in Escolta and other old haunts of Sonny's youth. Escolta, as those of you above 60 might recall, was Manila's fashionable district, yesteryear's Makati, the home of elegant shops catering to folks of a certain class. All of that was now gone. Stores and theaters were either shuttered, or abandoned and left to decay. We saw homeless poor sleeping on newspapers spread out on the sidewalks, a sight that was the complete antithesis of what the place once was. As we walked around, Sonny clicking away with his camera, muttering how this or that building, now in shambles, used to look- "like the ruins of Egypt" - Charlie simply looked on saying nothing. "Well, you know," I said, echoing Thomas Wolfe, "You can never go back home again."

As we were walking back to the station to catch the train, I suddenly noticed, to my dismay, that the ID bracelet I was wearing, one that Sonny had bought for me in Escolta in 1960, was missing. Its value, needless to say, was purely sentimental. Sensing this, later that evening Charlie proffered comfort via email by imagining "some young man finding the bracelet and giving it to the woman he would prize for the rest of his life." "So you see," he added, dispelling my never-going-home-again platitude, "there are many ways of returning."

If I belabored the incident above it is because I want to tell you how it was the presence of someone who cares-Charlie, in this instance-that made the narrative of a lover's gift more significant than it might have been. I most likely would have brushed aside the loss were it not for the fact that there was someone nearby who bore witness to our attempt to recoup the past that day during our stroll in Escolta. And that's exactly how I'm viewing you now as you sit in this room bearing witness to Sonny's oeuvre.

Now history, as you all know, is not merely a process of recording facts. It always involves the selection and interpretation of recalled facts. So it is with remembered personal history, and key in its analysis are the contradictions. For us-and here I seize the opportunity to speak for Sonny-the embrace of progressive politics was a turning point in our lives, our coming alive to the world, as it were. Recently 
someone gave me a copy of the memoir of civil rights worker John Perdew, a Harvard student who became one of "the Americus Four" jailed in the south for organizing against racial segregation in 1963. It struck me that we were in Cambridge at that precise moment, yet had absolutely no awareness of the state violence meted upon these citizens of conscience who had acted on their belief in democracy. News about this student was even printed in the Harvard Crimson, the college paper that we surely must have read! It was not until the massive protests against the Vietnam War, and the nationalist movement then burgeoning right here in the Philippines, that we finally began to pay attention.

That shift in consciousness catapulted us into a whole new world of political involvement. Exhilarating as this was, it would prove paradoxical because it brought into view what had previously remained hidden: the relations of power buried deep within female/male relationships. Progressive politics, even as it drew us together in a common venture and made us come alive, inevitably emerged as a fraught issue, one that finds no easy or final resolution. The other day Sonny gave a friend the gift of his slim volume on Rizal, Sisa's Revenge. Calling to thank me, the friend blurted out, "Sonny's a feminist." Feeling particularly playful, I quipped, "No." "In theory," she insisted.

It is not as though Sonny failed to give fair warning about what life was going to be like with him. "Reading and writing are my lifeblood," he'd told me. But how was a twenty-year-old naif to know the import of such a statement, much less to apprehend the reclusiveness essential to such activities? Still and all, I must say that Sonny is missing a major ingredient of masculinity. He is not ego-centered. He is not prone to calling attention to himself as needy men often do, nor has he given me the slightest impression that he perceives himself as unique or special. I also want to add that I have indeed known very few, if any, who possess his breadth and depth of learning. The case is that it has been the realm of the intellect, the life of the mind, if you will, that has sustained and rescued us from the dreariness and banality of the quotidian. It is also, of course, continuing to be a terrain of engagement and struggle.

On many counts, Sonny and I are no longer the same people we were fifty-five plus years ago. Incidentally, I did find my bracelet the morning after our Escolta trek. Charlie and I are both correct: you can never go home again, but there are many ways of returning. One of them is speaking before all of you who are bearing witness here today. 